\title{
C.P. Snow, Sputnik and the Cold War
}

\author{
JEA N NE G UILLEMIN
}

Security Studies Program, Massachusetts Institute of Technology, 1 Amherst Street, Cambridge, Massachusetts 02139, USA. Email: jeg@mit.edu

In his reflections on the divide between science and the humanities, C.P. Snow made only passing reference to the Cold War context of his epoch. Yet great challenges to science and its impact on human society were being played out in political arenas far from the protected academic enclave in which Snow lived and wrote. This article explores the hostile uses to which advanced science of the nineteenth and twentieth centuries were put in the name of national progress and security, and the contributions of philosophers and scientists influenced by humanism in attempting to undo the harmful consequences of such inventions, especially nuclear weapons.

\section{Introduction}

On 4 October 1957, the United States was taken off guard by the successful Soviet launching of Sputnik, a 183.9 pound space satellite, 23 inches in diameter. Three years before, the International Council of Scientific Unions had established a competition to invent a space vehicle that could monitor solar activity. The US presumption was that its scientists would win. Its loss to the Soviets was much more than a blow to the pride of American space engineers. An arch-enemy equipped with nuclear weapons had demonstrated its command of advanced satellite technology that might be used to attack America.

The Dominican nun who was my ninth-grade homeroom teacher was prescient about the repercussions. 'Because of Sputnik,' she announced solemnly to her class of girls in navy blue uniforms, 'even you will be expected to go to college.' Oddly enough, her message made sense. For years we hid under our desks in air-raid drills and, true scholastics, prayed for the conversion of the Russians to Catholicism. Obviously, the Soviet Union had outdone America in science education and we would fight back in full force, for the stakes were national security and protection of the country. In 1958, Congress passed the National Education Defense Act to strengthen school science curricula; by the time I graduated high school, the US government was giving millions in NDEA loans and graduate fellowships to many who were university bound, including women, like myself, who otherwise might have 
been limited to becoming secretaries or homemakers. The Cold War was real and intense.

\section{Arms and the Man}

In his reflections on the dangers of the divide between the sciences and humanities, C.P. Snow says little about the Cold War, then at its height, the same in England as in the United States. As if he himself were in space circling the earth, he offhandedly praises Sputnik as 'a feat of organization and a triumphal use of existing knowledge' and offers favourable evaluations of the education of Soviet scientists and engineers, as if Britain were invulnerable to Russian nuclear missiles.

In his reflections on the two cultures of science and the humanities, Snow begins with examples from the world of academic privilege in Cambridge and Oxford; until the Harry Potter series became popular, most people would not have understood his reference to dining at 'High Table', but, in his day, those who mattered immediately grasped its significance. Intent on the joyful pursuit of pure knowledge, those in basic science didn't care to talk with philosophers and writers, and apparently the feeling of their colleagues was mutual. British 'literary intellectuals' lived, Snow tells us, within the bubble of their historical interpretations and were, by and large, 'natural Luddites'. He also faults them for being slow to correct their misguided support of fascism. The famously mad poet Ezra Pound, a Mussolini mouthpiece, was one example; the Irish bard and Nobel laureate William Butler Yeats, who briefly supported the fascist Blackshirts, was another.

Trained as a physical chemist, Snow praises 'the scientific edifice of the physical world' as 'the most beautiful and wonderful collective work of the mind of man'. Few would contradict him. His contemporary, Isaiah Berlin, characterized the development of the natural sciences and technology as 'certainly the greatest success story of our time'. ${ }^{1}$ Without the advances of the seventeenth and eighteenth centuries in chemistry and physics, the industrial revolution of the nineteenth century - the leap from agriculture to efficient mechanical production - could not have taken place.

Yet, as often happens, amazing technological innovations take hold first, with moral and legal corrections ringing in only later. The industrial revolution exemplified this pattern. Yet Snow glosses over the human misery it caused in his own country, where the revolution started and where it generated extreme poverty, urban slums, epidemics, illiteracy, water and air pollution, and shortened life spans among factory workers.

Scientists were rarely part of the solution to these problems, but philosophers and writers were. In England, the influence of the Enlightenment, with its emphasis on individual freedom and reason, spurred the early reform movements. From Manchester, the centre of the industrial revolution, came Robert Owen, the utopian socialist influenced by Jeremy Bentham, whose communitarian message went well beyond Britain. In 1851, journalist Henry Mayhew's graphic London Labour and the London Poor inspired reform, and Charles Dickens' fictional depictions of poverty and child abuse had a deep impact on readers - Karl Marx was a great admirer. 
Resonating to these ideas, in the United States, progressives such as Jane Addams spurred the changes necessary to improve the living standards of workers and the urban poor and joined forces with no less an advocate than President Theodore Roosevelt. $^{2}$ If we listen to Snow, it seems that beyond their basic research and its potential for technological advance and profit, scientists have little to contribute to social remedies or policy, which, if true, is a kind of tragedy for human endeavours.

Snow also makes no mention of the fact that industrial-age technological inventions, from explosives to poison gases and munitions, also expanded the destructive dimensions of modern war. By replacing Napoleonic-era guns and cannons with repeating rifles, machine guns, and transportable mortars, they made the standing armies of nineteenth-century nations into better killing machines. In less than two decades, from the 1853-1856 Crimean War to the 1870-1871 Franco-Prussian War, battlefield casualties increased from thousands to the hundreds of thousands. In 1859 , during the Second Italian War of Independence, Jean-Henri Dunant described 40,000 combatants killed or wounded in one day in the Battle of Solferino, a stunning account that led to the creation of the International Red Cross. ${ }^{3}$ The combat deaths in the US Civil War (1861-1864) reached 205,000; another 415,000 soldiers died, mostly from infectious diseases, but also from wounds, accidents, and mistreatment in prisoner-of-war camps. Reformers such as Dunant spearheaded changes that protected the wounded and sick on both sides and the volunteers who cared for them. In 1863, the German-born American philosopher Franz Lieber wrote the framework for the US Rules of Land Warfare, a humane code of conduct that became the basis for the 1899 and 1907 Hague Conventions and subsequent efforts to restrain battlefield slaughter, criminalize the abuse of prisoners of war, and prevent the growing jeopardy to civilians in war zones. ${ }^{4}$

\section{Bombs Away}

The rise of nationalism in industrialized nations made it almost inevitable that the basic sciences would be exploited to invent advanced weapons. Patriotism demanded nothing less, even from scientists whose careers began with beneficent intent. In the First World War, despite the ban on chemical warfare in the Hague Conventions, German chemist Fritz Haber oversaw the launching of chlorine gas on Allied troops at Ypres, which began the wartime competition for even more lethal chemicals, such as phosgene and mustard gas to overcome the limits of trench warfare. ${ }^{5}$ The development of long-range bomber aeroplanes in the interwar years opened the way to visions of strategic 'total war' attacks behind enemy lines to attack cities and infrastructure. The bomber, perhaps the most important technical advance in modern warfare, was essential to this vision, which made every foot soldier and civilian a defenceless target. Despite the 1925 Geneva Protocol ban on chemical and biological weapons, in the mid-1930s, Italy used aeroplanes to attack Ethiopian troops with mustard gas, and, in their war with China, the Japanese mounted aerial chemical attacks starting in 1937 and used aeroplanes for germ weapon attacks on civilians in 1940-1942. 
The ultimate strategic weapon, of course, was the US atomic bomb - the creation of Manhattan Project physicists, chemists and engineers. ${ }^{6}$ Before making his decision to bomb Hiroshima and Nagasaki in August 1945, President Harry Truman was advised by his generals that some 225,000 American soldiers would die if the land and sea war against Japan continued; how should he balance these lives against those of the enemy Japanese? Truman sought counsel from his Interim Committee of eight civilian officials from the War and State departments. The committee included two scientists, chemist James Conant, president of Harvard University, and physicist Karl Compton, the president of MIT. The Interim Committee, putting maximum value on the protection of Allied troops, strongly recommended using the bomb 'as soon as possible'. Only one member, financier Ralph Bard, undersecretary of the Navy, urged Truman to give the Japanese an advance notice of two or three days because, he felt, the United States was 'a great humanitarian nation' and should help reduce the inevitable mass casualties. Bard's suggestion was ignored. An estimated 225,000 civilians were killed outright in the two August attacks. The ethics of Truman's decision are still debated.

Strikingly absent from Snow's essay is the UK experience of the Cold War and its decision to build an atomic bomb. After the end of the Second World War, the British were threatened by USSR expansion on the continent; as Winston Churchill described in March 1946, an Iron Curtain was ominously dividing communist bloc nations from the West. ${ }^{7}$ Since the United States, fearing espionage, refused cooperation, the United Kingdom felt compelled to develop an independent nuclear arsenal and recruited its experimental physicists to start the project. In 1949, when the Soviets detonated their first atomic bomb (code-named 'Joe-1' by the Americans), the pressure on the British project intensified. In 1952, the United Kingdom finally tested its first atomic weapon and remained competitive. That same year the United States tested the first hydrogen bomb; the next year, 1953, the Soviets tested their H-bomb (Joe-4). From 1957-1958, the British successfully conducted Operation Grapple, becoming the third nation to test a hydrogen bomb. In the eyes of its leaders, notably Churchill, this thermonuclear achievement made Britain a 'first-class nation' and it brought the benefit of a nuclear weapons pact with the United States.

Not surprisingly, Snow cites the hydrogen bomb as the world's number one problem, but without discussing its menace or how either scientists or humanists might offer solutions. Yet the role models were there in his time: Albert Einstein had become a post-war activist for restraint, along with Leo Szilard, the Hungarian physicist who in 1939 had written the letter for Einstein to sign proposing the Manhattan Project to President Franklin D. Roosevelt. In London in 1957, liberals and progressives, including the philosopher-mathematician Bertrand Russell, became united in the Campaign for Nuclear Disarmament, organized in reaction against the British H-bomb. In January 1958, the Nobel laureate in chemistry Linus Pauling and his wife Ava Helen presented to the United Nations a petition signed by 11,000 scientists from 43 countries urging a ban on above-ground nuclear testing, which was exposing the world to new and harmful radiation. (Five years later, in 1963, the Partial Nuclear Test Ban Treaty was signed by the United States, the Soviet Union, and the United 
Kingdom. Pauling received a Nobel Peace Prize for his work in influencing this accord.)

Today, despite the awarding of the 2017 Nobel Peace Prize to the International Campaign to Abolish Nuclear Weapons, this area of potential disarmament hardly inspires optimism. After the end of the Cold War, concern about atomic weapons faded, more than it should have. With the demise of the Soviet Union in 1992, USRussian disarmament agreements led to international stockpile reductions, but not their elimination. Ninety-three percent of nuclear arms are held by the United States and Russia, with each possessing around 4000-4500 warheads, enough to incinerate entire countries - if that were the objective. (France follows with 300, China with 270, and the United Kingdom with 215.) Henry Kissinger, George Schultz, William Perry, and Sam Nunn, all Cold War veterans, have campaigned for a nuclear-free world the goal of the framers of the 1968 nuclear Non-Proliferation Treaty (NPT). Biological and chemical weapons programs have been internationally banned for decades, why not nuclear ones? The accidents affecting arsenals (bombs lost at sea and detonations that almost happened) and the accumulation of nuclear waste, plus accidents such as the 2011 Fukushima Daiichi nuclear reactor disaster, point to hazards that few governments want to risk. Yet others argue that these strategic weapons have deterred warfare between states and that, despite the risks of an outmoded 'total war' weapon, they should be kept indefinitely.

The proliferation of nuclear arms to smaller and less industrially advanced nations has long posed a different set of problems. In tense regions in the Middle East and Asia, nuclear arsenals are as much the currency of power as they were for the major nations during the Cold War. ${ }^{8}$ India, Pakistan, Israel and North Korea have refused to be bound by the NPT, while Iran, a party to it, has complied only with difficulty, subject to special terms. The sobering lesson from nuclear arms history is that one nation's advanced weapon sooner or later can become the advanced weapon of other states and the potential source of regional or even world destabilization. As the United States and Russia, in a new phase of antagonism, prepare to modernize their nuclear attack capability and North Korea has built a capacity for launching longrange missiles, the need for reasonable perspectives seems imperative to avoid catastrophe. One can hardly help hoping for the appearance of a modern-day Pauling or Russell.

\section{STEMS and Genes}

As for today's cutting-edge science and technology, the divide between the two cultures is less extreme than it once was: the elite High Table conversations have spilled into the public realm, into a mix of different constituencies, not all guaranteed Western, secular, white or male. Two major revolutions, one in genetics and the other digital, have affected society at large, making for a new, scientifically-literate generation. STEM-savvy children in grade school are learning about DNA and the human biome, even as they become computer literate. For a small fee, anyone can by mail have their ancestry genetically tested and their vulnerability to genetically-based 
diseases revealed. Medical treatments based on new technological discoveries are rapidly emerging, with increasing exploitation of big data sources and genetic manipulations that could spur the quest to engineer a perfect human, however that might be defined.

Such relatively easy access to information and machines, which is increasingly global, raises three questions. The first is whether the benefits of these technologies, not yet fully realized but with great implications for medical advances, will be equitably shared or withheld from those lacking resources. The second question is if the destructive capacity of these innovations will be effectively controlled to prevent danger or harm. Indifference rather than malfeasance may be the worst jeopardy; as in the past, epidemics of old or new diseases indigenous to Africa or Asia might continue to be dismissed as irrelevant to prosperous nations. One need think only of the long histories of malaria and sleeping sickness or consider vacillating Western reactions to recent Ebola virus outbreaks in Africa. The third and most important question concerns how we can break the pattern of reacting to technological change only after its problems are entrenched and instead focus beforehand on protecting the public good, whether that public is in an affluent world area or an impoverished one. The answers lie not only with having scientists and humanists in dialogue, as Snow would agree, but with having threatened populations free to ask questions, open to learning and tolerance, and empowered to act.

As science moves forward, we can rely on traditional humanistic values that have informed it well for many years and hope they will be heard more clearly. In 1888, in a letter to the poet Alexey Pleshcheyev, the great writer and physician Anton Chekhov passionately expressed his ideal, one much worth remembering: 'My holy of holies is the human body, health, intelligence, talent, inspiration, love, and absolute freedom freedom from violence and falsehood, no matter how the last two manifest themselves." 9

\section{References}

1. I. Berlin (1979) Against the Current: Essays in the History of Ideas (London: Hogarth Press).

2. P.M. Shields (2017) Jane Addams: Progressive Pioneer of Peace, Philosophy, Sociology, Social Work and Pubic Administration (New York: Springer).

3. F. Bugnion (2009) From Solferino to the birth of contemporary humanitarian law. International Committee of the Red Cross, https://www.icrc.org/eng/resources/ documents/article/other/solferino-article-bugnion-240409.htm

4. F. Kalshoven (1985) Arms, armaments, and international law. Collected Courses of the Hague Academy of International Law, 191, pp. 183-342 (Dordrecht: Martinus Nijhoff Publishers).

5. Stockholm International Peace Research Institute (1973) The Problem of Chemical and Biological Warfare. Vol. 3: CBW and the Law of War (New York: Humanities Press).

6. R. Rhodes (1986) The Making of the Atomic Bomb (New York: Simon \& Schuster). 
7. W. Churchill (1946) Sinews of peace. 5 March, Westminster College, Fulton, Missouri, http://nebraskastudies.org/0900/media/0901_0102iron.pdf

8. J. Cirincione (2007) Bomb Scare: The History \& Future of Nuclear Weapons (New York: Columbia University Press).

9. A. Yarmolinsky (1947) The Portable Chekhov (New York: Viking Press).

\begin{abstract}
About the Author
Jeanne Guillemin is a Senior Advisor at the MIT Security Studies Program within the Center for International Studies. In addition to consulting for government agencies, she is the author of numerous articles and four books on the history of biological and chemical weapons, the most recent being Hidden Atrocities: Japanese Germ Warfare and American Obstruction of Justice at the Tokyo Trial (Columbia University Press, 2017).
\end{abstract}

